World Lumen Congress 2021 | May 26-30, 2021 | lasi, Romania

\title{
SMEs Sustainability in Times of Crisis
}

\author{
Otilia-Maria BORDEIANU, Claudia-Elena \\ GRIGORAS-ICHIM, Lucia MOROSAN-DANILA
}

https://doi.org/10.18662/wlc2021/07

How to cite: Bordeianu, O.-M., Grigoras-Ichim, C.-E., \& Morosan-Danila, L. (2021). SMEs Sustainability in Times of Crisis. In A. Sandu (vol. ed.), Lumen Proceedings: Vol. 17 World Lumen Congress 2021 (pp. 58-65). Iasi, Romania:

LUMEN

Publishing House. https://doi.org/10.18662/wlc2021/07 


\title{
SMEs Sustainability in Times of Crisis
}

\author{
Otilia-Maria BORDEIANU11, Claudia-Elena GRIGORAS-ICHIM², \\ Lucia MOROSAN-DANILA ${ }^{3}$
}

\begin{abstract}
The global crisis generated by the COVID-19 pandemic among the population and at the level of companies, state institutions, etc., underlined the importance of analysing its impact at different levels (intern, national and international level). The concepts of sustainability, development and growth must be aware, adapted and implemented more and more frequently, even constantly, in order to cope with the current evolution of the economy (and not only). The paper is an empirical research conducted in the North-East Region of Romania, aiming to analyse the impact of COVID-19 on local companies (especially SME's), in the context of existing correlation between the COVID-19 impact on resizing, restricting, changing the number of active employees, changing revenue, changing turnover and changing profit, based on the Spearman correlation coefficients. In this sense, it was important to implement sustainability strategies and ensure the activity and resources of companies in the long term, because the effects of an economic crisis (natural resources, buman resources, not only financial) are felt in 2021 and will be felt in the future 10 years. The paper concludes with two practical solutions to ensure the sustainability of the companies involved in the study, solutions that can be applied by all companies that have been affected by the COVID-19 pandemic.
\end{abstract}

Keywords: Development, sustainability, growth, SME, crisis, COVID-19, strategy.

\section{Introduction}

The coronavirus pandemic has brought about a radical change on all levels worldwide: government, health, business, travel, personal life, etc. Business environment registered huge modifications, in different sectors, most of them being obliged to adopt and implement policies, strategies and actions to deal with the crisis generated by COVID-19. These actions

\footnotetext{
1 Lecturer PhD, "Stefan cel Mare" University of Suceava, Suceava, Romania, otilia.bordeianu@,usm.ro.

2 Lecturer PhD, "Stefan cel Mare" University of Suceava, Suceava, Romania, claudia.grigoras@usm.ro.

3 Lecturer PhD, "Stefan cel Mare" University of Suceava, Suceava, Romania, lucia.danila@usm.ro.
} 
involve important changes caused by rethinking and reduction of activities, cost reduction and saving, drastic changes in operations, adoption of new technologies, and meeting new health requirements (Grigoras-Ichim et. al., 2020).

In the current economic context, the company's sustainability is even more important, the student being seen like ,a business and investment strategy that will use best business practices to meet and balance the needs of current and future stakeholders" (Artiach et. al., 2020).

In 2020 and 2021 maintaining sustainability and long-term business thinking is even more complicated, namely the certitude that companies should ensure a continuous development of the activity, both by satisfying short-term customer requests (both in terms of quantity and quality), and by trying to ensure (by protecting and reducing consumption) the necessary resources for generations to come. According to Mays (2003), the components of the entity's sustainability are:

- Community represented by civil liberties, logistics, goods value and security, goods feasibility, region evolution, humanitarianism.

- Human resources represented by diversity, labour rights, trade union treatment, remuneration, education, healthcare, employee safety.

- The environment consists of ecology, environmental control regulations, environmental report, waste disposal, supply administration, energy consumption, global heating guidelines and efficiency.

- Corporate governance represented by management principles, the governing body, rewarding executive staff, transparencies and stakeholder disclosure and presentation.

Crisis thinking and adaptation to market requirements stimulate the adaptation of immediate management strategies to those of sustainable management.

In the following content we present the analysis of sustainability in the context of financial reporting of the companies in times of crisis, and present at the end possible solution for SMEs sustainability in times of crisis.

\section{Methodology}

The subject of the analysis of accounting and financial reports was caused by the meaning that every company should take into account to this important origin of data for decision-making with regard to economic growth (Bordeianu \& Morosan-Danila, 2013), not only in times of crisis (Bostan \& Grosu, 2010; Lucaci \& Nastase, 2020; Nastase et. al, 2011). Thus, we conducted an exploratory research in which we followed a structured 
examination tool (questionnaire) trying to capture the most important details concerning the points of view / attitude of companies towards the crisis generated by COVID-19 (especially, in financial terms). The objective of the research presented below is to establish the role of financial reporting in decision-making in times of crisis, such as that generated by COVID-19.

\section{Analysis regarding the sustainability and COVID-19 crisis}

The sample targeted 240 companies from Suceava County, structured as presented in Figure 1. The sampling of statistical units was done by the simple typical selection procedure.

The financial reporting of companies can be very important in optimizing the costs of the company for about $30 \%$. Approximately $40 \%$ of the companies consider that the financial reports of the companies are of great importance in optimizing the costs of the company. For $2 \%$ of the entities, the importance of these financial reports in optimizing the costs of the company is very small.

Regarding the current crisis, the restriction of the company's activity related to the difficulties triggered by COVID-19 occurred to a very large extent for $23.36 \%$ of the companies participating in the research, respectively to a large extent for $32.37 \%$. For $13.11 \%$ of the companies, the activity restriction was achieved to a very small extent.

The change in the value of turnover after the onset of the COVID19 crisis occurred to a very large extent in $28.68 \%$ of the companies participating in the research, respectively to a large extent for $36.88 \%$. For $5.73 \%$ of the companies, the change in turnover was made to a very small extent.

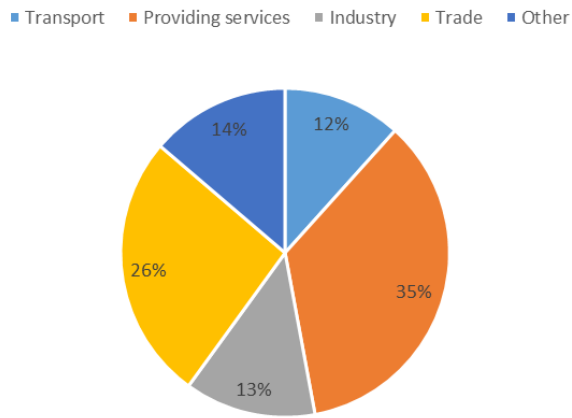

Figure 1. Distribution of respondents according to the field of activity Source: Authors' own processing according to the research performed 
In the short term, $34.42 \%$ of the companies consider that the activity of the company will not change, while for $39.75 \%$ of the companies they consider that the activity of the entity will register increases in the next period. The perspective is not a good one for $23.26 \%$ of the respondents, $2.45 \%$ considering that the activity will be completely stopped.

Related to the current difficulties triggered by COVID-19, approximately $70 \%$ of the companies consider that the financial reporting supports the organization and development of activities. A rather large share of over $20 \%$ do not know how to appreciate the relevance of these reports in the current context, and $11 \%$ consider that the reports cannot support the organization and development of activities related to the current difficulties triggered by COVID-19.

Testing the existence and intensity of the correlation between the importance of using information from financial statements and the extent to which there were effects on economic indicators of the company related to the difficulties triggered by COVID-19, was performed using the Spearman coefficient and the results were centralized in the table 1.

The centralized results in the table 1 show that there are strong correlations (Spearman coefficients greater than 0.5) and significant (sig coefficient being less than 0.01) between the importance given to the use of information in the financial statements and the extent to which the activity of was affected by the crisis triggered by COVID-19.

Table 1. Spearman correlation coefficients

\begin{tabular}{|l|c|c|c|c|c|c|c|}
\hline $\begin{array}{c}\text { The } \\
\text { Company's } \\
\text { Coefficient } \\
\text { decisions } \\
\text { are based } \\
\text { on } \\
\text { information } \\
\text { from the } \\
\text { financial } \\
\text { statements }\end{array}$ & Resize & Collapse & $\begin{array}{c}\text { Change } \\
\text { no. } \\
\text { Employee }\end{array}$ & $\begin{array}{c}\text { Change } \\
\text { of } \\
\text { receipts }\end{array}$ & $\begin{array}{c}\text { Turnover } \\
\text { change }\end{array}$ & $\begin{array}{c}\text { Changing } \\
\text { the value } \\
\text { of profit }\end{array}$ \\
\hline $\begin{array}{l}\text { The company's } \\
\text { decisions are } \\
\text { based on } \\
\text { information } \\
\text { from the } \\
\text { financial } \\
\text { statements }\end{array}$ & 1,000 & $0,732^{* *}$ & $0,569^{* *}$ & $0,646^{* *}$ & $0,720^{* *}$ & $0,796^{* *}$ & $0,803^{* *}$ \\
\hline Resize & & 1,000 & $0,735^{* *}$ & $0,909^{* *}$ & $0,750^{* *}$ & $0,893^{* *}$ & $0,890^{* *}$ \\
\hline Collapse & & & 1,000 & $0,711^{* *}$ & $0,486^{* *}$ & $0,702^{* *}$ & $0,707^{* *}$ \\
\hline
\end{tabular}




\begin{tabular}{|l|l|l|l|l|l|l|l|}
\hline $\begin{array}{l}\text { Change no. } \\
\text { Employee }\end{array}$ & & & & 1,000 & $0,730^{* *}$ & $0,814^{* *}$ & $0,812^{* *}$ \\
\hline $\begin{array}{l}\text { Change of } \\
\text { receipts }\end{array}$ & & & & & 1,000 & $0,706^{* *}$ & $0,776^{* *}$ \\
\hline $\begin{array}{l}\text { Turnover } \\
\text { change }\end{array}$ & & & & & & 1,000 & $0,929^{* *}$ \\
\hline $\begin{array}{l}\text { Changing the } \\
\text { value of profit }\end{array}$ & & & & & & & 1,000 \\
\hline
\end{tabular}

** Correlation is significant at the 0.01 level (2-tailed).

Source: Source: Processing of research results through the SPSS program

For most companies, the consequences of the COVID-19 crisis on the company's activity are visible to a large and very large extent by: resizing, restricting, changing the number of active employees, changing revenue, changing turnover and changing profit. The evolution of the company's activity in the next period is not foreseeable to be a good one for $23.26 \%$ of the companies, and $2.45 \%$ considering that the activity will be completely stopped.

Regarding the current difficulties triggered by COVID-19, approximately $70 \%$ of companies, however, consider that they can support the organization and development of activities on financial reporting to ensure the sustainable development of the company.

\section{Recommendation for sustainability in a crisis}

The analysis shows that company's report (accounting and financial) involves the being of a financial state within the entity, which guaranties the repetition of reporting (Grigoras-Ichim \& Morosan-Danila, 2020), while maintaining a certain level of worth that is the basis of the operation of taking the decision that responds rapidly to all modifications and problems posed by the business environment, by also the social and political ones, especially in regard to the economic activities affected by the COVID-19 crisis (Morosan-Danila \& Bordeianu, 2020a, 2020b; Tonnoir et. al, 2021).

Following the study of the specialized literature and the research results, the following development directions in the field of financial reporting in the context of sustainable development are proposed:

1. It is recommended that companies question the transfer of the results presented by the financial statements to the decision-making process of companies that wish to overcome potential economic turmoil and ensure the sustainable development of their companies. Managers of companies 
must impose a decision-making system based on real information, obtained through stable processes based on methodologies. The decision is based on various parameters influenced by the accounting policies, national, international or internal regulations of the company, such as: laws in force, European directives, national and international financial reporting standards.

2. It is necessary for companies to apply models for evaluating the performance of the company, in the light of the financial indicators presented by the financial statements to ensure the sustainable development of companies. It is recommended that specialized software be used to focus on organisation and enhance upcoming achievement preferably to retrospective evaluation of former fulfilment and ensuring the necessary base for an organized, systematized, performance-oriented decision-making process and the sustainable development needs of the future company.

\section{Conclusions}

Accounting information, presented in financial and economic indicators, represent the main source of information on the financial position of the company, performance and changes in financial position (Socoliuc et. al, 2018; Grigoraş-Ichim \& Morosan-Danila, 2016; Boghean et. al, 2009, 2011), the basis for substantiating management decisions and to ensure the sustainable development of the company. The high degree of credibility that the information in the financial reports presents for the stakeholders, underlines the importance of the financial-accounting system in achieving the performance indicators of the company (immediately or later on), as well as in sense of stable growth.

In terms of the current economic context, companies around the world are still struggling with the crisis generated by COVID-19, a crisis that has severely affected the concept of sustainability at the company level. The analysed correlations demonstrate the need to identify and implement viable solutions to overcome the crisis, and, implicitly, to ensure a sustainability of the business, both in terms of turnover, profit, number of employees and revenues.

\section{References}

Artiach, T., Lee, D., Nelson, D., \& Walker, J. (2010). The determinants of corporate sustainability performance. Accounting \& Finance, 50(1), 31-51. https://doi.org/10.1111/j.1467-629X.2009.00315.x 
Boghean, F., Boghean, C., \& Danila, L. M. (2009). Use by Managers of Accounting Information Provided in the Implementation Strategies. Bulletin UASVM Horticulture, 66(2), 2009. https://www.semanticscholar.org/paper/Use-bymanagers-of-accounting-information-provided-BogheanBoghean/3a6b2ec2f7247b2c3327d00d06599a3197ad3d1

Boghean, F., Boghean, C., \& Morosan-Danila, L. (2011). Approaches and advances in the use of the financial-accounting information in the decision-making and innovative process. Revista Economica [Economic Magazine], 3(56), 34-44.

Bordeianu O. M, Morosan Danila L. (2013). Development and Validation of Research Instruments for Cross-Cultural Studies in Economics and Management [Conference Presentation]. 20h International Economic Conference IECS 2013, Sibiu, Romania.

Bostan, I., \& Grosu, V. (2010). The social effects of the current economic crisis on the European Union labour market. Revista de cercetare si interventie sociala [Journal of research and social intervention], 31, 7-21. https://ideas.repec.org/a/lum/rev2rl/v31y2010ip7-21.html

Grigoraş-Ichim, C. E., \& Morosan-Danila, L. (2016). The Importance of Financial Interim Reporting for the Position of Companies. The USV Annals of Economics and Public Administration, 15(2), 182-187. https://www.semanticscholar.org/paper/THE-IMPORTANCE-OFFINANCIAL-INTERIM-REPORTING-FOR-Ichim-Moro\%C2\%AAanDanil\%C3\%A3/1d9e86f7912648c035db6f1ee5cac2ebfc1e6595

Grigoras-Ichim, C.-E., \& Morosan-Danila, L. (2020). Analysis of the Correlation Managerial Decisions - Interim Financial Statements. LUMEN Proceedings, 11, 203-211. https://doi.org/10.18662/lumproc/gekos2020/21

Grigoras-Ichim, C.E., Bordeianu, O.M., \& Morosan-Danila, L. (2020). Corporate sustainability in times of crisis. Conference Competitiveness and sustainable development. In Conference Competitiveness and sustainable development. 2nd edition. https://ibn.idsi.md/ro/collection view/818

Lucaci, A., \& Nastase, C. (2020). European Rural Businesses During The Covid-19 Pandemic: Designing Initiatives For Current And Future Development. LUMEN Proceedings, 13, 419-429. https://doi.org/10.18662/lumproc/ncoe4.0.2020/38

Mays, S. (2003). Corporate Sustainability-an Investor Perspective: The Mays Report. Assistant Secretary. Environment Protection Branch. Department of the Environment and Heritage. Australian Gouvernament. http://www.arema.com.au/media/mays-report.pdf

Morosan-Danila, L., \& Bordeianu, O. M. (2020a). Human resources management in times of crisis. In Competitiveness and sustainable development 2, 42-42.

Morosan-Danila, L., \& Bordeianu, O.-M. (2020). The Need For Change And Shaping The Post-COVID Business Environment in Romania. LUMEN 
Proceedings, 13, 387-397.

https://doi.org/10.18662/lumproc/ncoe4.0.2020/35

Năstase, C., Popescu, M., \& Scutariu, A. L. (2011). Aspects regarding the global crisis and its impact on tourism industry. Revista Economică [Economic Magazine], 55(2), 475-482.

https://ideas.repec.org/a/blg/reveco/v55y2011i2p475-482.html

Socoliuc, M., Grosu, V., Hlaciuc, E., \& Stanciu, S. (2018). Analysis of social responsibility and reporting methods of Romanian companies in the countries of the European Union. Sustainability, 10(12), 4662. https://doi.org/10.3390/su10124662

Tonnoir, A., Ciotir, I., Scutariu, A. L., \& Dospinescu, O. (2021). A Model for the Optimal Investment Strategy in the Context of Pandemic Regional Lockdown. Mathematics, 9(9), 1058. https://doi.org/10.3390/math9091058 